\title{
Convergent acquisition of antibiotic resistance determinants amongst the Enterobacteriaceae isolates of the Mhlathuze River, KwaZulu-Natal (RSA)
}

\author{
J Lin ${ }^{1 *}$ and PT Biyela ${ }^{2}$ \\ ${ }^{1}$ Department of Microbiology, University of KwaZulu-Natal (Westville campus), Private Bag X54001, Durban 4000, South Africa \\ ${ }^{2}$ Department of Biochemistry and Microbiology, University of Zululand, Private Bag X1001, KwaDlangezwa, 3886, South Africa
}

\begin{abstract}
The Mhlathuze River has become a major reservoir for antibiotic-resistant microbes and a wide pool of antibiotic resistant genes with the environmental isolates exists in this water system. The ability of commensal organisms to carry resistant genes of clinical importance and their ability to transfer such genes to other bacteria are of greater concern than phenotypic measurements. Forty-three Enterobacteriaceae isolates, which were capable of resisting more than 4 different classes of antibiotics, were used for the molecular characterisation of antibiotic resistances. It was found that $58 \%$ of these multiple antibiotic-resistant isolates possess the Class 1 integron. Amongst these 25 isolates with positive detection of the Class 1 integron, the beta-lactamase gene ( $p s e$ ) was the most common, being present in $44 \%$ of these integrons. The aminoglycoside-resistant gene was detected in $16 \%$ of these integrons and $24 \%$ of Class 1 integrons contained two genes coding for sulphonamide resistance and for quaternary ammonium compounds resistance. A high degree of genotypic diversity and the lack of correlation between antimicrobial resistance patterns and molecular types of the isolates suggest convergent acquisition of resistance determinants by genetically unrelated strains rather than epidemic spread of resistant isolates in the community. Of the tested environmental isolates, $56 \%$ transferred their plasmids as well as their antibiotic resistance profiles to the recipient cells. The possibility of transmission of resistant genes between bacteria (especially pathogenic) which invade human and animal populations within this river poses a health risk to the communities who are dependent on this river for water consumption.
\end{abstract}

Keywords: Mhlathuze River, antibiotic resistance, conjugation, Enterobacteriaceae, Class I intergron

\section{Introduction}

The Mhlathuze River in northern KwaZulu Natal, South Africa, flows into the estuary at Richards Bay and supports a rapidly growing agricultural and industrial community (Steyl et al., 2000). The results of the microbiological evaluation of this river (Bezuidenhout et al., 2002; Lin et al., 2004a) show high levels of total and faecal coliform contamination. The majority of the Enterobacteriaceae isolates from this water system also carry antibiotic-resistant gene(s) especially the $\beta$-lactamase genes (Lin et al., 2004b). Ash et al. (2002) and Park et al. (2003) also reported that several rivers in the USA as well as in South Korea have become major reservoirs for antibiotic-resistant microbes. A strong correlation $(r=0.97)$ of antibiotic-resistance profiles between the clinical and the environmental isolates was observed in this region suggesting a strong link between diarrhoeal incidence and water quality (Lin et al., 2004b).

Given the propensity of the Enterobacteriaceae family and clinically significant bacteria to acquire antimicrobial resistance, consistent surveillance of the agents commonly prescribed to treat infections arising from these organisms is imperative (Sahm et al., 2000). These organisms could create a widespread antibiotic-resistant gene pool. These genes could be transferred into human and animal disease organisms (Kruse and Sorum, 1994), which subsequently could generate significant health and economic impacts.

\footnotetext{
* To whom all correspondence should be addressed.

뚕 +2731 260-7407; fax: +2731 260-7809;

e-mail: linj@ukzn.ac.za

Received 18 October 2004; accepted in revised form 15 February 2005.
}

Antibiotic-resistant genes are carried on either chromosomes or mobile genetic elements e.g. plasmids; integrons, etc. These mobile gene elements with antibiotic- or metal-resistant genes can be transferred between different species through transformation, conjugation and transduction (Madigan et al., 2003). It is therefore important to track antibiotic-resistant genes in a variety of commensal, pathogenic and environmental bacteria in order to measure the environmental pool of resistance and to understand the ecology of antibiotic resistance (Aminov et al., 2001; Goni-Urriza et al., 2000). Aquatic (river) ecosystems are ideal since they may support a wide array of micro-organisms e.g. indicator organisms, faecal and total coliforms, pathogens, animal and human, commensals, human and animals as well as environmental bacteria.

Until recently, studies on antibiotic resistance were only concerned with the collection of phenotypic data. However, in order to study the environmental pool of resistant genes and to understand the molecular ecology of antibiotic resistance the development of genotyping tools is indispensable (Aminov et al., 2001).

Drug resistance especially multiple-drug resistance (MR) in enteric organisms is often associated with integrons. Integrons generally contain an integrase gene (intI) and a cassette integration site (attI), into which antibiotic-resistant gene cassettes have integrated. A gene cassette contains an antibiotic resistance gene and a 59 base pair (bp), a short inverted repeat element with a recombination site. Four classes of chromosomal and plasmidborne integrons in gram-negative bacteria have been described (Bass et al., 1999). Class 1 integrons are the most common and have been found primarily in complete or truncated derivatives of the Mu- like transposon $T n 402$, which resides in a wide range of host plasmids or within $\operatorname{Tn} 21$. They generally contain the qua- 
ternary ammonium compound resistance gene qacE $\Delta$ and the sulphonamide-resistant gene sull in the 3' conserved region. The 5' and 3' regions flank gene cassettes, which contain single or multiple antibiotic-resistant gene(s). The integron acquires or exchanges antibiotic-resistant genes with its specialized recombinase (Bass et al., 1999). These genetic elements are responsible for linking antibiotic-resistant genes together to form large multiple loci of antimicrobial resistance within the genome.

This paper reports on the microbial diversity and the stability of antibiotic-resistance conferring genes of the environmental isolates in the Mhlathuze River, KwaZulu-Natal.

\section{Materials and methods}

\section{Isolation of bacteria}

All water samples were collected from 5 different sites along the Mhlathuze River from March 2001 to January 2002 and analyzed within $6 \mathrm{~h}$ of collection as described in the previous report (Lin et al., 2004a,b).

A series of tenfold dilutions of the water samples from different sites were inoculated into different varieties of media (nutrient agar, TSA, R2A, m-Endo and $\mathrm{mFc}$ ). Plates were incubated for a 2-week period at $25^{\circ} \mathrm{C}, 37^{\circ} \mathrm{C}$ and $44^{\circ} \mathrm{C}$ as described by the manufacturer. The plates were monitored everyday. The colonies with the distinct morphology from different media plates were randomly selected for further identification. The isolates were then identified using Gram stain and biochemical reactions (Standard Methods, 1998) and confirmed by API strips applied according to the manufacturer's instructions (BioMerieux, France).

Of 113 environmental isolates belonging to the Enterobacteriaceae family, 43 , which were resistant to more than 4 different classes of antibiotics (Lin et al., 2004b), were used for the genetic study.

\section{DNA isolation}

Total DNA isolation of each micro-organism from the environmental sample was obtained using the heat-lysis method (Sandvang et al., 1997). The plasmid extraction was performed using the GFX $^{\mathrm{TM}}$ Micro plasmid Preparation Kit (Roche). The DNA profile of the plasmid from the isolates was analysed on a $0.7 \%$ agarose gel (stained with ethidium bromide) to determine their sizes.

\section{Enterobacterial repetitive intergenic consensus (ERIC) profiles of the Enterobacteriaceae isolates}

The PCR amplifications were performed using the method of Versalovic et al. (1994) with ERIC2 primer (5'-AAGTAAGTGACTGGGGTGAGCG-3'). The PCR conditions for all experiments were $94^{\circ} \mathrm{C}$ for $4 \mathrm{~min}$, followed by 35 cycles of $94^{\circ} \mathrm{C}$ for $1 \mathrm{~min}, 35^{\circ} \mathrm{C}$ for $60 \mathrm{~s}$ and $72^{\circ} \mathrm{C}$ for $2 \mathrm{~min}$ and finally for $4 \mathrm{~min}$ at $72^{\circ} \mathrm{C}$. All ERIC products were analyzed using $1 \%$ agarose gel and recorded by SynGene Gel Documentation system.

\section{Detection of the Class 1 integron and the antibiotic- resistant genes associated with the Class 1 integron}

Different sets of primers were used in this study. The presence of the Class 1 integron was screened with a primer set of int $1 \mathrm{~F}$ and sul1B. (Dalsgaard et al., 1999) Positive samples were then used to amplify the fragment of the variable region of the integron with a primer set of int $1 \mathrm{~F}$ and int $1 \mathrm{~B}$. The Class 1 integron PCR products were purified using Qiagen PCR product purification kit (Roche). The purified product was used as a template for the detection of beta-lactam-resistant gene (pse) (Naas et al., 1999), aminoglycoside-resistant gene (ant'3), the quaternary ammonium compound-resistant gene $(q a c \Delta E 1)$ and the sulphonamide-resistant gene (sul1) (Dalsgaard et al., 1999). The PCR conditions for all integron experiments were $94^{\circ} \mathrm{C}$ for $5 \mathrm{~min}$, followed by 35 cycles of $94^{\circ} \mathrm{C}$ for $1 \mathrm{~min}, 65^{\circ} \mathrm{C}$ for $30 \mathrm{~s}$ and $72^{\circ} \mathrm{C}$ for $2 \mathrm{~min}$ and finally for $5 \mathrm{~min}$ at $72^{\circ} \mathrm{C}$. All PCR products were analyzed on agarose gel (1\%). The gels were stained with ethidium bromide and visualised under UV light. A molecular mass size marker was also loaded on the gel for band size determination.

\section{Conjugation experiments}

Conjugation was carried out for 16 isolates representative of the different antibiotic resistance patterns (10 E.coli; 3 Klebsiella spp.; 2 C.freundii and $1 S$. marcesens) using the double selection method described by Govender (2002).

Antibiotic sensitivity/resistance patterns of the trans-conjugants were determined and compared to those of the donors (environmental isolates) prior to conjugation. Plasmid DNAs were extracted from the successfully conjugated isolates. Molecular mass of the purified plasmids was determined using gel electrophoresis with $0.7 \%$ agarose gel.

\section{Results}

All common micro-organisms found in the freshwater environment were isolated using a variety of media, minimal salt agar, R2A, at room temperature and identified during the study. These micro-organisms which included E. coli, Bacillus, Chromobacterium, Corynobacterium, Alcaligene faecalis, Brucella, Neisseria, Flavobacterium, Micrococcus, Staphylcoccus and Streptococcus spp. as well as Mycobacterium spp. Nitrobacter spp. Hafnia spp. and Thiobacterillus spp. were widely distributed in the Mhlathuze River.

The micro-organisms which were isolated from the nutrient agar, m-Endo at $37^{\circ} \mathrm{C}$ and $\mathrm{mFC}$ plates at $44^{\circ} \mathrm{C}$ included mainly Enterobacteriaceae, Pseudomonas spp. and Aeromonas hydrophila. The Proteus spp. were only isolated from the Richards Bay Estuary. The populations of E. coli and C. freundii were usually small in the estuary while Klebsiella, Pseudomonas/ Aeromonas and Enterobacter spp. were well-distributed at all five sites. No pathogenic E. coli strains or other water-borne pathogens, such as Vibrio cholerae and Salmonella spp., were detected in the samples from the Mhlathuze River during the study period.

The ERIC profiles of $E$. coli and $C$. freundii isolates with multiple antibiotic resistances are shown in Figs. 1A and 1B. The results clearly reviewed the genetic diversity of the environmental isolates of the Mhlathuze River.

Of the 43 Enterobacteriaceae isolates that were used for the molecular characterization of antibiotic resistances, 25 yielded PCR products with the general integron 1 primer set. The size of the integrons ranged from 0.8 to $2.0 \mathrm{~kb}$. Some of the isolates contained more than one copy of Class 1 integron of different sizes. These PCR products were purified and used to quantify the integrons with sets of diagnostic primers. The beta-lactamase gene was the most common, being present in $44 \%$ of the integrons. The aminoglycoside-resistant gene was present in $16 \%$ of the Class 1 integrons. Two genes (sul1 and the qac $\Delta E 1$ coding for sulphonamide resistance and quaternary ammonium compounds resistance, respectively) were detected in $24 \%$ of these integrons. However, there was no clear correlation between anti- 
Figure 1

Examples of ERIC profiles of (A) E. coli (1: isolate 6/181601; 2: 15/141101, 3: $9 / 101001 ; 4: 9 / 031201$ and 5 :

12/031201) and (B) C. freundii (1: 4/031201; 2: 5/031201; 3: 3/101001; 4: 8/241001; 5: 2/180601; 6 : 3/210102; 7: 8/141101; 8: 2/101001;

9: 10/260301; 10: 6/031201; 11: 3/010801; 12: 7/141001) with multiple antibiotic resistance isolated from the Mhlathuze River. M: molecular marker XVI (Roche Biochemical)
A

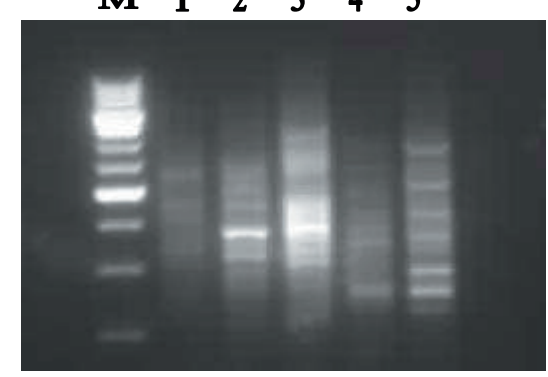

B

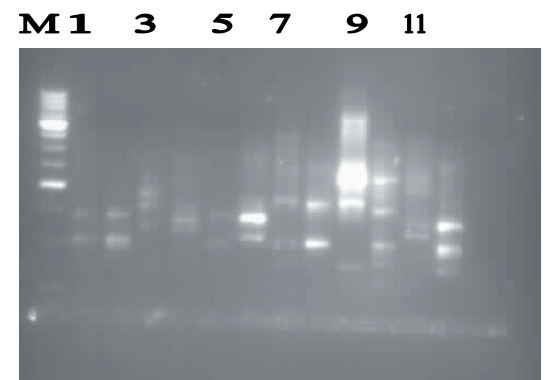

biotic resistance patterns and the integron/gene profiles.

In the conjugation experiments, 6 of 10 E.coli, 2 of 3 Klebsiella spp. and 1 of 2 C. freundii were successfully transferred to recipient cells. Antibiotic resistance patterns of the trans-conjugants were the same as those of the donors (environmental isolates) with the exception of one E. coli isolate 12/031201. This E. coli isolate developed resistance to nalidixic acid after the conjugation process. The plasmids, which were trans-congugated from the donors to the recipient cells, were about $10 \mathrm{~Kb}$ in size.

\section{Discussion}

Most of the micro-organisms isolated from the Mhlathuze River are frequently found in the river water and soil. These microorganisms are mostly involved in the cycles of carbon, nitrogen and sulphur compounds (Madigan et al., 2003).

Enterobacteriaceae, Pseudomonas spp. and Aeromonas hydrophila were commonly isolated using nutrient agar, $\mathrm{m}$-Endo at $37^{\circ} \mathrm{C}$ and $\mathrm{mFC}$ agars at $44^{\circ} \mathrm{C}$. (Goni-Urriza et al., 2000) Aeromonas hydrophila, is associated with gastroenteritis and Pseudomonas aeruginosa, on the other hand, reportedly affects patients that are either immuno-compromised or have metabolic or haematological disorders (Pearson et al., 2000). The presence of opportunistic pathogens including Klebsiella spp. may have serious implications for the consumers of the river water, especially young children, the elderly and those infected with HIV/AIDS. According to statistics of the Department of Health of South Africa, KwaZulu-Natal Province has an HIV prevalence rate of $32.5 \%$, the highest in South Africa. In 1999 $30 \%$ of the state hospital bed space in the Jozini/Empangeni region was occupied by HIV patients (KZN, 1999).

The results of the ERIC profiles of the Enterobacteriaceae isolates from the Mhlathuze River strongly suggest that the Enterobacteriaceae isolates possess a high degree of genetic diversity within the same species in this area.

The majority of the Enterobacteriaceae isolates from this water system exhibited resistance to the presence of antibiotics (Lin et al., 2004b). The fact that these organisms could create a widespread antibiotic-resistant gene pool and the ability of micro-organisms especially the pathogenic organisms to acquire new resistance genes through horizontal transfer (Bunny et al., 1995), can subsequently have detrimental consequences for the health system and the economics of the Province. It is therefore important to track antibiotic-resistant genes in a variety of commensal, pathogenic and environmental bacteria in order to measure the environmental gene pool of resistance and to understand the molecular ecology of antibiotic resistance. (Aminov et al., 2001; Goni-Urriza et al., 2000).

Drug resistance especially multiple-drug resistance (MR) in enteric organisms is often associated with integrons, especially the Class 1 integron. Fifty-eight percent of MR enteric bacterial isolates in this study possessed the Class 1 integron, which is much higher than that reported by Park et al. (2003) who showed that $24 \%$ of 150 coliform isolates contained the Class 1 integron.

The results from this study show that some isolates possessed more than one copy of the Class 1 integron which varied in size. These findings are supported by Daly and Fanning (2000) who found two replicas of the Class 1 integron with different molecular masses present in one bacterial isolate. The integron sizes vary depending on how many cassettes are inserted adjacent to the integrase gene.

Amongst the 25 isolates with positive detection of the Class 1 integron, the beta-lactamase gene ( $p s e$ ) was the most common being present in $56 \%$ of these integrons. The aminoglycosideresistant gene (ant'3) was found in 16\% of the integrons. However, there was no clear correlation between antibiotic resistance patterns and the integron/gene profiles as reported by Park et al. (2003). Park et al. (2003) suggest that in the absence of sustained antibiotic pressures, such as the natural environment, coliform bacteria may carry empty or non-functional Class 1 integrons.

In the science of antibiotic resistance, the mutation rate is frequently defined as in vitro frequency at which defective mutants arise in a bacterial population in the presence of a given antibiotic concentration (Collin and Hall, 1995). Therefore phenotypic data report only selectively favourable bacterial mutations. The problem is complicated by the fact that the phenotype does not always reflect the same genotype in all "selected" mutants, because mutations in different genes can produce similar antibiotic-resistant phenotypes. A number of factors, e.g. cassette position, affect the level of expression of antibiotic-resistant genes in integron-associated cassettes. Collis and Hall (1995) reported that the expression of genes was greatest when the cassette was proximal to the promoter and reduced by the presence of preceding cassettes. This is because the efficiency of translation could be affected by the presence of upstream cassettes. Loss of upstream cassettes led to an increase in the resistance conferred by the gene. Another factor that might influence the level of expression of antibiotic-resistant genes is the copy number of the plasmid. All these factors may be significant not only in the maintenance but also in the spread of antibiotic resistance between environmental and clinical bacteria.

The results of this study show that a pool of antibiotic-resistant genes exists within this water system. The difference in integron sizes and random distribution of the integrons across different genera indicates the possibility of horizontal gene transfer within this river system. A high degree of genotypic diversity and the lack of correlation between antimicrobial resistance patterns and molecular types of the isolates suggest convergent acquisition of resistance determinants by genetically unrelated strains rather than epidemic spread of resistant isolates in the community.

With the ability to transfer amongst different bacterial spe- 
cies, mobile genetic elements (i.e. integrons and plasmids) have the capacity to disseminate antibiotic resistance within bacteria in the aquatic environment. In this study, conjugation was successful in $56 \%$ of the cases studied. The antibiotic resistance profiles of those trans-conjugant cells were the same with those of donors with the exception of one $E$. coli trans-conjugant.

Three main mechanisms of gene transfer, namely transformation, transduction and conjugation, occur naturally in aquatic environments. (Madigan et al., 2003) Aquatic environments are reservoirs for a large gene pool of bacterial DNA. Extracellular DNA can be derived from dead and viable cells. Many viable cells release DNA without cell lysis suggesting that a release of genetic materials may be a normal function of bacteria. In the aquatic environment, free or bound DNA may be moved by percolation of water, flows of air, water or dust. The half-life of free DNA is longer in aquatic environments ( 0.017 to $235 \mathrm{~h})$ compared to that in terrestrial environments (9.1 to $28.2 \mathrm{~h}$ ) (Yin and Stotzky, 1997). In the natural environment, the presence of stressors, e.g. antibiotics, heavy metals, decreased nutrient levels, microbial competition for the available space and nutrients, etc. are capable of inducing a physiological state of competence in bacterial cells "enabling" the bacteria to actively take up DNA from the environment.

\section{Conclusion}

From the results of this diverse study one can conclude that there exists a pool of resistance genes within the Mhlathuze River. Commensal bacteria are important reservoirs of antibiotic-resistant genes. The ability of commensal organisms to carry resistant genes of clinical importance and their ability to transfer such genes to other bacteria are of greater concern than phenotypic measurements. This suggests the possibility of transmission of resistant genes from the commensal organisms to pathogenic organisms. This calls for studies to determine the extent to which transmission of antibiotic-resistant bacteria occurs and the extent to which such transfer impacts on the efficacy of antibacterial use in human medicine. The possibility of transmission of resistance genes between bacteria (especially pathogenic bacteria) which invade human and animal populations within this river poses a health risk to the communities who are dependent on this river for water consumption.

\section{Acknowledgement}

The authors wish to thank the National Research Foundation (GUN 2038429) and the Water Research Commission (K5/1282) for the financial support of this study.

\section{References}

AMINOV RI, GARRIGUES-JEANJEAN N and MACKIE RI (2001) Molecular ecology of tetracycline resistance: Development and validation of primers for detection of tetracycline resistance genes encoding ribosomal protection proteins. Appl. Environ. Microbiol. 67 (1) $22-32$.

ASH RJ, MAUCK B, and MORGAN M (2002) Antibiotic resistance of gram-negative bacteria in rivers, United States. Emerging Infect. Dis. 8 (7) 713-716.

BASS L, LIEBERT CA, LEE MD, SUMMERS AO, WHITE DG, THAYER SG and MAURER JJ (1999) Incidence and characterization of integrons, genetic elements mediating multiple-drug resistance, in avian Escherichia coli. J. Antimicrob. Agents Chemother 43 (12) 2925-2929.
BEZUIDENHOUT CC, MTHEMBU N, PUCKREE T and LIN J (2002) Microbiological evaluation of the Mhlathuze River, KwaZulu-Natal (RSA) Water SA 28 (3) 1-6.

BUNNY KL, HALL RM and STOKES HW (1995) New mobile gene cassettes containing an Aminoglycoside-resistant gene, aacA7, and a chloramphenicol resistance gene, catB3, in an integron in pBWH301 J. Antimicrob. Agents Chemothe. 39 (3) 686-693.

COLLIS CM and HALL RM (1995) Expression of antibiotic-resistant genes in the integrated cassettesof integrons, J. Antimicrob. Agents Chemother. 39 (1) 155-162.

DALSGAARD A, FORSLUND A, TAM N, VINH D and CAM P (1999) Cholera in Vietnam: Changes in genotypes and emergence of Class I integrons containing Aminoglycoside-resistant gene cassettes in Vibrio cholerae 01 strains isolated from 1979 to 1996. J. Clin. Microbiol. 37 (3) 734-741.

DALY M and FANNING S (2000) Characterization and chromosomal mapping of antimicrobial resistance genes in Salmonella enterica Serotype Typhimurium. Appl. Environ. Microbiol. 66 (11) 4842-4848.

GOÑI-URRIZA M, CAPDEPUY $M$, ARPIN C, RAYMOND N, CAUMETTE P and QUENTIN C (2000) Impact of an urban effluent on antibiotic resistance of riverine Enterobacteriaceae and Aeromonas spp. Appl. Environ. Microbiol. 66 (1) 125-132.

GOVENDER A (2002) Mobilisation and Sequence Analysis of a Plasmid Indigenous to Xanthomonas albilineans. M.Sc. dissertation, University of Durban Westville.

KRUSE H and SORUM H (1994) Transfer of multiple drug resistance plasmids between bacteria of diverse origins in natural micro-environments. Appl. Environ. Microbiol. 60 4015-4021.

KWAZULU-NATAL (KZN) (1999) KwaZulu-Natal Annual Report. KwaZulu-Natal Health Department, South Africa,

LIN J, BIYELA PT, PUCKREE T and BEZUIDENHOUT CC (2004a) A study of the water quality of the Mhlathuze River, KwaZulu-Natal (RSA): Microbial and physico-chemical factors. Water SA 39 (1) 16-22.

LIN J, BIYELA PT and PUCKREE T (2004b) Antibiotic resistance profiles of environmental isolates from Mhlathuze River, KwaZuluNatal (RSA). Water SA 39 (1) 23-28.

MADIGAN MT, MARTINKO JM and PARKER J (2003) Brock: Biology of Microorganisms. (10 ${ }^{\text {th }}$ edn.) Pearson Education Inc., USA

NAAS T, POIREL L, KARIM A and NORDMAN P (1999) Molecular characterization of In50, a class 1 intergron encoding the gene for the extended-spectrum beta-lactamase VEB-1 in Pseudomonas aeruginosa. FEMS Microbiol. Lett. 176 (2) 411-419.

PARK JC, LEE JC, OH JY, JEONG YW, CHO JW, JOO HS, LEE WK and LEE WB (2003) Antibiotic selective pressure for the maintenance of antibiotic-resistant genes in coliform bacteria isolated from the aquatic environment. Water Sci. Technol. 47 (3) 249-253.

PEARSON JP, FELDMAN M, IGLEWAKI BH and PRINCE (2000) Pseudomonas aeroginosa cell-to-cell signalling is required for virulence in a model of acute pulmonary infection. Infect. Imm. 68 (7) 4331-4334.

SAHM DF, PTERSO DE, CRITCHLEY IA and THORNSBERRY C (2000) Analysis of ciprofloxacin activity against Streptococcus pneumoniae after 10 years of use in the United States. J. Antimicrob. Agents Chemother. 44 (9) 2521-2524.

SANDVANG D, AGRESTRUP FM and JENSEN LB (1997) Characterization of integrons and antibiotic resistance genes in Danish multi-resistant Salmonella enterica Typhimurium DT 104. FEMS Microbiol. Lett. 157 (1) 177-181.

STANDARD METHODS (1998) Standard Methods for the Examination of Water and Waste Water. Clesceri L.S, Greenberg A E and Eaton A D (eds.) American Public Health Association $\left(20^{\text {th }}\right.$ edn.) Washington DC.

STEYL I, VERSFELD DB and NELSON PJ (2000) Strategic Environmental Assessment for Water Use: Mhlathuze Catchment KZN. DWAF Report No SEA-01/2000.

VERSALOVIC J, SCHNEIDER M, DE BRUIJN FJ and LUPSKI JR (1994) Genomic fingerprinting of bacteria using repetitive sequence-based polymerase chain reaction, Methods Mol. Cell. Biol. 5 25-40.

YIN X and STOTZKY G (1997) Gene transfer among bacteria in natural environments. Adv. Appl. Microbiol. 45 153-212. 